\title{
Investment Promotive Effects of Mega-FTAs on the Cooperative Game for Eurasia Initiative
}

\author{
Nany Hur*
}

\begin{abstract}
The policy choices of Eurasian states whether to form a coalition along with the "Eurasia Initiative" can be explained by the cooperative game theory. While the each bilateral relationship before making a binding agreement seems to be a non-cooperative game, the coalitions with many other states through a binding agreement of Mega-FTA would be a cooperative game. Despite the lack of numerical data, this study at least tries to show the possibility of applying the game theory to analyze the "Eurasia Initiative" and it's the impacts of Mega-FTAs on this ambition. While the Eurasia Initiative necessarily involves some economic projects requiring enough investment promotion, Korea can strategically set up the policies linked with the development of Mega-FTAs. To utilize the investment promotive effect of Mega-FTAs, Korea has to assure that the core of the cooperation game would be the grand coalition of a Mega-FTA. If it continues to search for the best policies to maximize the superadditivity of this cooperative game, Korea will finally be able to achieve the co-promotion of Mega-FTAs and the Eurasia Initiative.
\end{abstract}

Key Words: Mega-FTA, Eurasia Initiative, cooperative game, investment promotion

\footnotetext{
* World Economic Law Research Center, School of Law, Korea University, Sungbook-Gu Anamro 145, Seoul, South Korea, E-mail: nanyhur@korea.ac.kr.
} 


\section{Introduction}

With the ambition to revive the "Silk Road", President Park Geun-hye proposed the "Eurasia Initiative" in October 2013. Although various non-economic concerns have pursued this initiative, whether it can be realized or not heavily depends on the economic analysis since the ultimate goal is to promote trade and investment through the "Silk Road" which eventually pursues the overall economic integration. Another important goal of this initiative is to pull out North Korea's participation by its economic judgement. Therefore, while Korea is now pushing ahead its active policy for Free Trade Agreements (FTAs), economic integrations among Eurasian states would likely to encourage this ambition in the near future. Also, since "Mega-FTAs" would broaden the boundary of the economic coalition, Eurasian states are likely to be involved in dynamic forms of coalitions requiring comprehensive policy concerns.

The policy choices of Eurasian states whether to form a coalition along with the "Eurasia Initiative" can be explained by the cooperative game theory. While the each bilateral relationship before making a binding agreement seems to be a non-cooperative game, the coalitions with many other states through a binding agreement of Mega-FTA would be a cooperative game. However, an analysis based on the game theory has not yet been attempted yet. Despite the lack of numerical data, this study at least tries to show the possibility of applying the game theory to analyze the "Eurasia Initiative" and it's the impacts of Mega-FTAs on this ambition. Specifically, this study focuses on the reciprocal investment promotion set up with the bilateral investment treaties (BITs), which has a much longer history compared to the trade liberalization, to narrow down the focus of the study. Then, since 'treaties' work as the method of making binding agreements in international relations, international legal analysis on different forms of treaties regarding reciprocal investment promotion is included in this study. After the comparison between BITs and FTAs, how the Mega-FTAs would likely to contribute to the "Eurasian Initiative" will be proved through the cooperative game theory.

\section{Eurasia Initiative as a Cooperation in the Game of Investment Promotion}

\subsection{Fundamental Goals of Eurasia Initiative: Towards the Investment Promotion}

According to the Ministry of Foreign Affairs, "Eurasia Initiative" is to build "One 
Continent," "Creative Continent," and "Peaceful Continent". 1) It is mainly aimed at the economic integration with the Eurasian states by collaborative multilateral economic projects related to logistics, transport, energy, science and technology, then improve the security in Korean Peninsula by involving North Korea in multilateral economic cooperation which will gradually contribute to the inter-Korean trust building. The key element which can concretize this initiative would be the strengthened networks of logistics and energy in Eurasia through the railroads, namely the "Silk Road Express (SRX)".

Eventually, all these goals inevitably require the investment promotion in the region to fund each project. Mainly, regarding the connection of the SRX, foreign direct investment (FDI) which assists the construction of the railroad would be the key issue to realize the initiative. While Korea needs to boost its investment to the Eurasian states as a leader of this initiative, the investment environment in those states should be improved through their 'cooperation' of investment promotion. By allowing favorable conditions for foreign investors reciprocally, Korea and Eurasian states can 'collectively' promote mutual investment and thus crystallize the economic integration. Here, the process of deciding whether to participate in this cooperation itself can be seen as the 'non-cooperative' game among the two rational players when it comes to the bilateral negotiation.2) Once the players decide to make a bilaterally binding agreement, it would be a step forward to the final goal of the initiative which is to promote investment and strengthen economic ties. More detail of applying the game theory in pursuing the "Eurasia Initiative" is as follows.

\subsection{Analysis based on the Game theory: the players, payoffs and strategies}

For the basic set of the game, the players, payoffs, and the following strategies need to be defined considering the concept of the Eurasia Initiative. The assumptions for this game set may seem intuitive without specific numerical data to define the elements of the payoffs. However, the overall effect of each choice can be expected through political and legal analysis being generally accepted.

\subsubsection{Definition of "Eurasia" and the list of Eurasian states: Players}

1) For more information, refer to the Ministry of Foreign Affairs' official document to explain the concept of "EurAsia Initiative" available at http://www.mofa.go.kr/ENG/image/common/title/res/0707 eurasia_bro.pdf

2) 'Cooperation' can exist as a 'solution' of the non-cooperative game along with each rational player's choice based on the strategies without a 'coordination'. See (Weirich, 2010), p. 140. 
Defining Europe and Asia together as "One Continent", the initiative seeks to connect the Far East starting from the Republic of Korea, Siberia, Central Asia crossing Ural and Gafkas Mountains, East and West Europe, and finally arriving in London, UK. Thus, all the states widely spread in the region may be included as the 'players' of this game of investment promotion.3) As the leader of the "Eurasia Initiative", Korea is the player 1 and each Eurasian state individually would be another player in the game of bilateral investment promotion $(\mathrm{i}=2)$. Especially considering the inter-Korean relation, the neighboring states of North Korea - e.g., China and Russia - are the key players of this cooperation of the investment promotion. As it is a basic strategic game, each player is a 'rational' decision maker who consistently pursues the self-interest, in other words, national interest.

\subsubsection{Investment Promotion through the Protection on the Foreign Investors and Investment Market Liberalization: Strategies}

There are two kinds of strategies for the rational players in this game of investment promotion: (1) to maintain the status quo without any investment market liberalization or (2) to provide protection to the foreign investors and liberalize its investment market foreign (inward) investment promotion. ${ }^{4)}$ Since each state has the limited jurisdictions, it can only open up its domestic investment market, not being able to liberalize the other state's investment market. Here, let's assume that the players takes actions in accordance with their 'pure strategies'5) since there is not yet any expectable probability distribution in this game. As explained above, the investment relation derives from the "Eurasia Initiative" should take into account various concerns of each state which makes it unable to define probability of the player's choice. Other external factors such as the possibility of North Korea's cooperation may also affect the players' choices of their strategies.6) However, to simplify the analysis, the payoff matrix in this study excludes any non-economic interests from external factors and only shows national interests directly resulted from the investment relations.

3) Since the term 'Eurasia' is a contentious one without any consensus on its scope, geo-political concerns of each state are to be reflected (Mostafa, 2013). For example, Russia named the customs union with Kazakhstan and Belarus as the 'Eurasian Economic Union (EEU)' since 2012.

4) Here, the meaning of 'foreign investment promotion' is widely defined as including both the mere provision of protection to the foreign investors and the active measures of investment market liberalization through deregulation.

5) Unlike the 'mixed strategies' which also reflects the probability of each action, 'pure strategies' only define a specific move or action that a player will follow in every possible attainable situation in a game.

6) Especially regarding the reconnection of the 'Silk Road', North Korea's participation is necessary to completely achieve this goal. 


\subsubsection{Benefits and Losses arising from the Foreign Investment Promotion: Payoffs}

The payoffs in this game are each Eurasian state's national interests affected by the other player's foreign investment promotion. If all the players decides to maintain the status quo without any foreign investment promotion, there will be no change in their national interest. If only one of the players promote foreign investment, the other player's overseas (outward) investment would increase with this investment market liberalization. In other words, there will be an increased inflow of foreign investment into the domestic investment market of the player who has chosen to promote the strategy of 'investment promotion' without any increase of its own overseas investment. If both of the players equally decides to promote mutual investment, they will share the increase of both foreign and overseas investment.

Importantly, there are multiple sides of the increase of the overseas and foreign investment.7) The increased overseas investment may bring the revenues from the foreign market back to the domestic economy with the investment market expansion and the increased employment, but it may also loose the capital and potential revenues which might have been generated in the domestic economy. On the other hand, the increased foreign investment would likely to develop the domestic economy since it can generate more revenues including the technology spill-over effect and improved productivity, but the resources may be exploited and the regulatory authority would be limited.

\section{Table 1.}

Benefits and Losses from the Overseas and Foreign Investments

\begin{tabular}{|c|c|}
\hline \multirow{2}{*}{$\begin{array}{l}\text { As a Home Country of } \\
\text { the Overseas Investment } \\
\text { (Outward) }\end{array}$} & $\begin{array}{l}\text { Benefits : revenues from the foreign market, reduced production cost } \\
\text { with cheap labor, reduced unemployment with job increase, increased } \\
\text { exports, etc. }\end{array}$ \\
\hline & $\begin{array}{l}\text { Losses : capital outflow, reduced industrial development in domestic } \\
\text { economy, etc. }\end{array}$ \\
\hline \multirow{2}{*}{$\begin{array}{l}\text { As a Host Country of the } \\
\text { Foreign Investment } \\
\text { (Inward) }\end{array}$} & $\begin{array}{l}\text { Benefits : technology spill-over effects, improved productivity, reduced } \\
\text { unemployment with job increase, and greater economic growth, etc. }\end{array}$ \\
\hline & $\begin{array}{l}\text { Losses : domestic competitors' disadvantage of increased competition, } \\
\text { concerns on the market erosion of foreign investors, limitation on the } \\
\text { domestic regulations and national sovereignty, etc. }\end{array}$ \\
\hline
\end{tabular}

7) See for example, (Borensztein, Gregorio, and Lee, 1998), (Kim, Seung-jin, 2000), (Head and Ries, 2001), (Lipsey, 2004), (Tang, 2015). 
Even though the above Table 1 generally explains benefits and losses of the outward and inward investment, the effects may vary depending on each state's domestic policies and economic situations. For example, in Korea, "the outward FDI generally tends to affect employment and productivity positively, but the outward FDI into China exerted negative effect" (Ahn, 2005). On the other hand, even though "the inward FDI has played a negligible role throughout Korea's economic development, it had a significant impact on the quality of Korean economic development by spinning out skilled workers and managers and through technical guidance of subcontractors" (Kim and Hwang, 2000). Putting aside any specific analysis on the factors of benefits and losses, the below Table 2 shows the simplified payoff matrix which reflects different effects of overseas and foreign investment.

Table 2.

Payoff Matrix of the Investment Promotion Game

\begin{tabular}{c|c|c}
\hline & Status Quo & Investment Promotion \\
\hline Status Quo & $(0,0)$ & $\left(\mathrm{a}_{1}, \mathrm{~b}_{2}\right)$ \\
\hline Investment Promotion & $\left(\mathrm{b}_{1}, \mathrm{a}_{2}\right)$ & $\left(\mathrm{a}_{1}+\mathrm{b}_{1}, \mathrm{a}_{2}+\mathrm{b}_{2}\right)$ \\
\hline
\end{tabular}

Note: 1$) \mathrm{a}=$ Effects of the overseas investment to the foreign economy $=\mathrm{a}^{\prime}-\mathrm{a}^{\prime \prime}\left(\mathrm{a}^{\prime}>0=\right.$ value of benefits, $\mathrm{a}^{\prime \prime}>0=$ value of losses), 2) $b=$ Effects of the foreign investment coming into the domestic economy $=b^{\prime}-b^{\prime \prime}\left(b^{\prime}>0=\right.$ value of benefits, $b^{\prime \prime}>0=$ value of losses)

\subsubsection{Whether to Make an Investment Treaty for a Reciprocal Investment Promotion: Solution}

As the players are pursuing for the best of their own national interest, the equilibrium will be settled by the each player's individual choice - reaching the "Nash Equilibrium".8) Since the players cannot consult each other beforehand, a player would take the strategy based on the comparison of the payoffs considering all the possible choices of the other player. According to the payoff matrix in Table 2, if the player 1 stays at the status quo, it would get 0 if the player 2 also maintains status quo, or $\mathrm{a}_{1}$ if the player 2 unilaterally promotes foreign investment. On the other hand, the choice of investment promotion would bring $b_{1}$ to player 1 if player 2 stays status quo, or $a_{1}+b_{1}$ if the player 2 also promotes foreign investment reciprocally. Thus, the player 1 would choose to promote foreign investment only if the following is satisfied:

8) "Nash Equilibrium" refers to the optimal outcome of a game where no player has an incentive to deviate from his or her chosen strategy after considering an opponent's choice. An individual can receive no incremental benefit from changing actions, assuming other players remain constant in their strategies. 


$$
0<b_{1} \text { and } a_{1}<a_{1}+b_{1}
$$

Here, we can see that regardless of the value of $a_{1}\left(a_{1}>0\right.$ or $\left.a_{1}<0\right)$, the player 1 would choose to promote foreign investment if $0<b_{1}$. Eurasian states would be more sensible to the effects of foreign investment inflow rather than the increase of outward investment. The same logic applies to the player 2 . Only if $0 \triangleleft \mathrm{b}_{2}$, the player 2 will decide to promote foreign investment. Therefore, the following must be satisfied also.

$$
0<b=b^{\prime}-b^{\prime \prime} \rightarrow 0<b^{\prime}-b^{\prime \prime} \rightarrow b^{\prime \prime}<b^{\prime}
$$

Thus, only when the value of benefits from the foreign investment coming into the domestic economy $\left(b^{\prime}\right)$ is bigger than the value of loss $\left(b^{\prime \prime}\right)$, the players would likely to take action of investment promotion and this would be a 'dominant strategy' for this game. This means than if Korea wants to successfully have a reciprocal investment promotion through a binding agreement with Eurasian states, there need policies to guarantee more benefits than losses from the inward foreign investment not only in Korea but also in the other Eurasian states.

\section{Investment Promotion through Investment Treaties: BITs and FTAs}

Once the equilibrium is settled, specific conditions to implement this compromise need to be promised through a binding agreement. In the international community, a 'treaty' carries legal binding force to assure the mutual investment promotion between the party states. While the final outcome of this game of investment promotion is the signing of an investment treaty, Korea's investment treaty practices would be influential to its further implementation of the "Eurasia Initiative".

\subsection{Different Methods of Investment Promotion: BITs v. FTAs}

There are two kinds of bilateral treaties which can be a binding agreement between the players: BITs and FTAs. Historically, BITs have been a major tool for guaranteeing protection on the foreign investors to promote investment. Developed from the 'protection of the aliens', BITs have been aimed at preventing an abuse of host country's domestic regulations which may harm the foreign investors and their investments (Sornarajah, 1994). Generally, BITs defines 'investment' quite broadly to extensively cover all kinds of foreign 
investment (UNCTAD, 2011). Principles such as non-discrimination, fair and equitable treatment, and expropriation with the proper compensation are contained in these BITs, formulating foreign investor-friendly environment (Lo, 2008). Also, the investor-state dispute settlement (ISDS) system, which grants an investor the right to directly use dispute settlement proceedings against a foreign government, has been introduced through BITs. With the emerged inclination to attract foreign investment for their economic growth since 1980s (UNCTAD, 1999), most states have already signed BITs with many other states.9)

Most of BITs by Korea have been signed since 1980s with its rapid economic development. Among its 86 BITs, Korea has 57 BITs with Eurasian states (including European, Asian, and Middle East countries). Having been signed before the "Eurasia Initiative", the investment environment under these BITs would be regarded as the "status quo' by each Eurasian state during the game with Korea.

\section{Table 3.}

Contracting Parties of Korea's BITs in Force (by August, 2015) ${ }^{10)}$

\begin{tabular}{|c|c|}
\hline & Contracting Parties of BITs in force (Total: 86) \\
\hline $\begin{array}{l}\text { European } \\
\text { (31) }\end{array}$ & $\begin{array}{l}\text { Germany('67), the United Kingdom('86), France('79), Denmark('88), Hungary('89), } \\
\text { Poland('90), Russia('91), Austria('91), Italia('92), Uzbekistan('92), Lithuania('93), } \\
\text { Turkey('94), Spain('94), Czech('95), Greece('95), Tadjikistan('95), Finland('96), } \\
\text { Portugal('96), Kazakhstan('96), Latvia('97), Ukraine('97), Sweden('97), Belarus('97), } \\
\text { the Netherlands('05), Slovakia('06), Albania('06), Croatia('06), Bulgaria('06), } \\
\text { the Azerbaijani Republic('08), Rumania('08), the Kyrgyz Republic('08), } \\
\text { Belgium.Luxemburg('11) }\end{array}$ \\
\hline Asian (17) & $\begin{array}{l}\text { Sri Lanka('80), Bangladeshi('88), Malaysia('89), Thailand('89), Pakistan('90), } \\
\text { Mongolia('91), Indonesia('94), India('96), Laos('96), the Philippines('96), } \\
\text { Cambodia('97), Hong Kong('97), Japan('03), Brunei('03), Vietnam('04), China('07), } \\
\text { China·Japan('14) }\end{array}$ \\
\hline $\begin{array}{l}\text { Middle } \\
\text { East (9) }\end{array}$ & $\begin{array}{l}\text { Egypt('97), Qatar('99), Saudi Arabia('03), Israel('03), Oman('04), United Arab } \\
\text { Emirates('04), Jordan('04), Iran('06), Lebanon('06) }\end{array}$ \\
\hline $\begin{array}{c}\text { Africa } \\
(13)\end{array}$ & $\begin{array}{l}\text { Tunisia('75), Senegal('85), South Africa('97), Nigeria('99), Morocco('01), } \\
\text { Algeria('01), Mauritania('06), Libya('07), Mauritius ('08), Gabon('09), } \\
\text { Burkina Faso('10), Congo('11), Rwanda('13) }\end{array}$ \\
\hline $\begin{array}{l}\text { America } \\
\text { (16) }\end{array}$ & $\begin{array}{l}\text { Paraguay('93), Peru('94), Argentina('96), Bolivia('97), Nicaragua('01), } \\
\text { Honduras('01), Panama('02), El Salvador('02), Mexico('02), Guatemala('02), } \\
\text { Costa Rica('02), Trinidad and Tobago('03), Guyana('06), Jamaica('07), } \\
\text { Dominica('08), Uruguay('11) }\end{array}$ \\
\hline
\end{tabular}

9) Accumulatively, there have been 2,929BITs worldwide by 2015. See UNCTAD, "Investment Policy Hub", available at http://investmentpolicyhub.unctad.org/IIA (last visited on August 28, 2015).

10) Source: (Byun, 2010), updated by the author. 
Meanwhile, traditional FTAs had been basically for the trade liberalization, focusing on the reduction of tariffs at the regional level. However, recent FTAs have broadened their scope to deal with more comprehensive issues - trade in services, intellectual property, and sustainable development - aiming at the regional economic integration. ${ }^{11)}$ Then, since NAFTA in 1994, FTAs began to substitute BITs by including the 'investment chapter'. The investment chapter in a FTA generally has the contents of BITs for investor protection and also BIT-plus provisions for investment market liberalization. ${ }^{12)}$ Due to this new trend of 'investment chapters', many BITs have been replaced by FTAs. For example, the following BITs of Korea have been replaced by recent FTAs: Korea-Swiss BIT ('71) $\rightarrow$ Korea-EFTA FTA ('06), Korea-Chile BIT ('99) $\rightarrow$ Korea-Chile FTA ('04), Korea-Peru BIT ('94) $\rightarrow$ Korea-Peru FTA ('11), Korea-Turkey BIT ('94) $\rightarrow$ Korea-Turkey FTA ('15). Also, even though not yet being in force, the investment chapters of Korea-China FTA ('15) and Korea-Vietnam FTA ('15) would likely to replace former BITs.

\section{Table 4.}

Korea's FTAs with the Investment Chapter (by August, 2015) ${ }^{13)}$

\begin{tabular}{c|l}
\hline FTAs in force with the Investment Chapter & $\begin{array}{l}\text { Chile('04), Singapore('06), India('10), Peru('11), } \\
\text { U.S.('12), Australia('14), Canada('15) }\end{array}$ \\
\hline $\begin{array}{c}\text { FTAs in force with the Investment Agreement } \\
\text { being a Part of the FTA }\end{array}$ & EFTA('06), ASEAN('07), Turkey('13) \\
\hline FTAs in force without the Investment Chapter & $\begin{array}{l}\text { EU('11): BITs with each EU members are to be } \\
\text { remained }\end{array}$ \\
\hline
\end{tabular}

\subsection{Different Impacts of BITs and FTAs on the Payoffs from the Investment Promotion}

The emergence of the investment chapter in FTAs would be the natural result of historical relevance between trade and investment (Alford, 2014). Also, an empirical study has shown this inter-relationship and their mutual influence (Footer, 2013). With the purpose of economic integration, trade liberalization may eventually bring the increase of

11) See WTO's official website for more information on the trend of recent FTAs, available at https://www.wto.org/english/tratop_e/region_e/region_e.htm

12) Provisions such as the national treatment and most-favoured nation principles at the establishment stage of foreign investment, transparency, prohibition of performance requirement, rules of origin with the denial of benefits can be categorized as 'investment market liberalizing provisions'. See "Table 1 Assessing Investment Chapters of RTAs" in (Houde, Kose-Patil and Miroudot, 2007).

13) See the official website of the Ministry of Trade, Industry \& Energy for Korea's FTAs (In Korean), available at http://www.fta.go.kr/main/ 
mutual investment. On the other hand, this inflow of capital from the FTA party would enhance the productivity which enlarges the trade volume. Thus, for FTAs with the final goal of 'economic integration', it was inevitable to exclude investment issues when pursuing overall system of the market economy developed with the capitalism.

Another important reason for FTAs to include the investment chapter is to promote investment not only from the FTA parties but also from the third countries (Qingiang, 2013). While the traditional BITs have been mainly aimed at protecting foreign investor's rights, the FTAs with 'trade liberalization' have actively included market access provisions for 'investment liberalization', encouraging the FDI inflow (Miroudot, 2011). Some BITs had market access provisions, however, their investment liberalizing effect was far less than the FTA due to different purposes and structures (Berger, 2013). According to the OECD's study, there has been "an insignificant effect of BITs on investment flows, which suggests either that substantive investment provisions in FTAs impact trade and FDI flows more profoundly, or that the combination of substantive investment rules and provisions liberalizing other parts of the economy jointly impact trade and investment more significantly" (Lesher and Miroudot, 2006).

Therefore, we can assume that the 'mutual investment promotion effect' would be greater in FTAs than mere BITs, especially regarding inward foreign investment. Applying this fact to the payoffs matrix in table 2, the following must be satisfied to see a FTA as a better strategy than a BIT to maximize the national interest from the mutual investment promotion:

\section{$b$ under FTA $>b$ under BIT $=0$ (Status Quo) \\ bunder FTA $\geq b^{\prime}$ under BIT, $b^{\prime \prime}$ under FTA $\leq b^{\prime \prime}$ under BIT}

As the FTA involves not only the active investment liberalization but also the trade liberalization, the external factors of trade in goods and services would affect positively on the benefits from investment promotion - such as technology spill-over effects, improved productivity, reduced unemployment with job increase, and greater economic growth. In contrast, the losses at least would not be greater than in the case of a BIT (status quo). First, since the provisions of FTA investment chapter are mostly the same as the former BITs regarding foreign investor protection, there would not be a greater limitation on the domestic regulations and national sovereignty. Second, as the concerns on the domestic competitors' disadvantages and the market erosion are already taken into account during the negotiation process of FTAs, the safeguards built in the FTAs would be able to prevent more losses from the deeper economic integration. 


\section{Investment Promotive Effect of Mega-FTAs Affecting the Eurasia Initiative}

As seen above, the more positive effects of FTAs on the mutual investment promotion account for the rapid increase of FTAs and the FTA-friendly policy of Korea. Now, breaking the tradition of bilaterality, FTAs have gradually became 'plurilateral' with multiple states. The most expanded form of a FTA, so-called "Mega-FTAs", has just emerged recently along with the increase of regionalism against the delayed multilateral trade negotiations. Since there also will be the investment chapter in these FTAs, their investment promotive effect related with the Eurasia Initiative would influence future strategies of Korea.

\subsection{Emergence of Mega-FTAs and Their Investment Promotive Effects}

Since June 2005, the Trans-Pacific Partnership (TPP) Agreement has been negotiated as the first Mega-FTA. With the purpose of the economic integration among the Asia-Pacific region, the U.S. has been the leader of TPP negotiation since its participation in 2008. Meanwhile, to confront the hegemony of the U.S., China and ASEAN have led the negotiations of another Mega-FTA, namely the Regional Comprehensive Economic Partnership (RCEP) Agreement since 2012. Both FTAs correspond to the idea of the Free Trade Area of the Asia-Pacific (FTAAP), which has been suggested in 2006 APEC Economic Leaders' Meeting. Together with another Mega-FTA, the Transatlantic Trade and Investment Partnership (TTIP) between the U.S. and the EU which has been negotiated since 2013, these Mega-FTAs are likely to cover all the Eurasian states. 


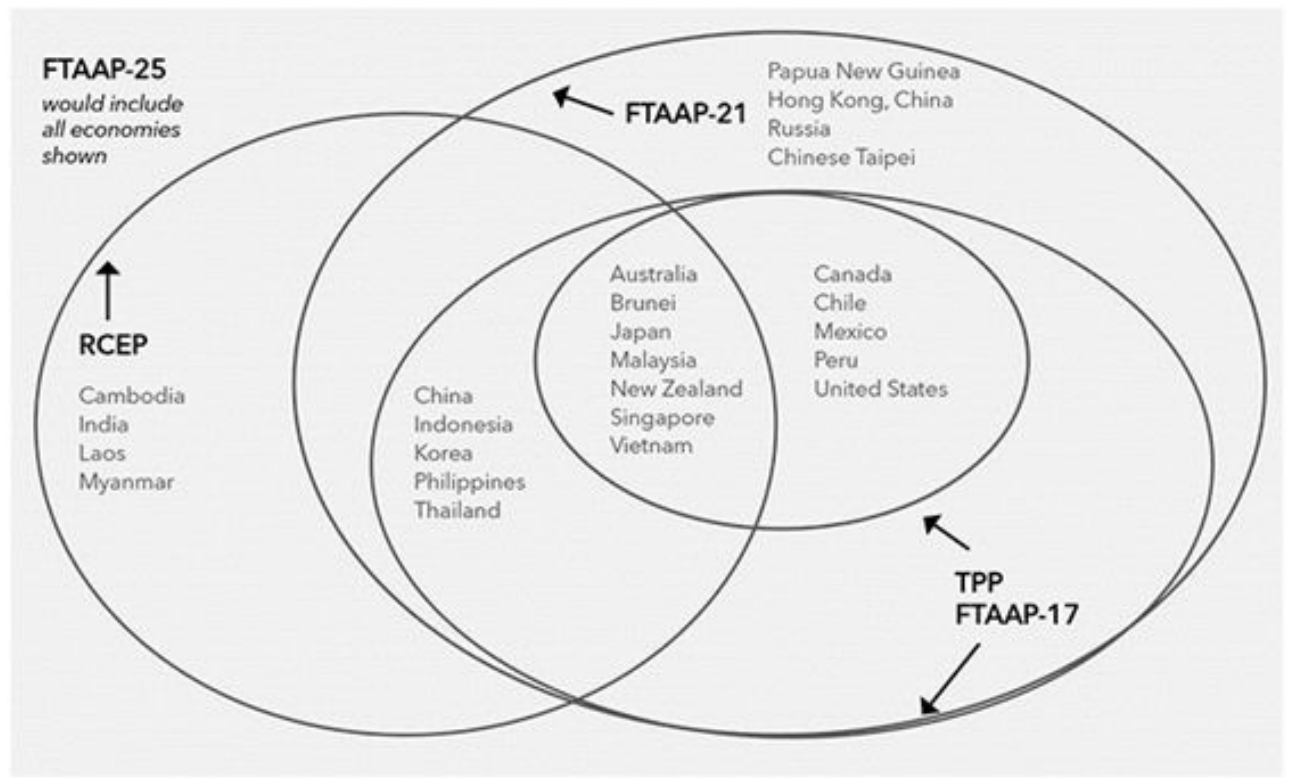

Figure 1.

Membership of Possible Asia-Pacific Trade Agreements

Specifically regarding the investment promotion, TPP has the objectives such as: (1) the liberal access for investment and legal protection for investors; and (2) expeditious, fair and transparent investor-state dispute settlement (Petri and Abdul-Raheem, 2014). Also, RCEP has the objectives such as: (1) the liberal, facilitative, competitive investment regime; and (2) promotion, protection, facilitation and liberalization of investment (Petri and Abdul-Raheem, 2014). Along with the positive external effect of trade liberalization, the investment promotive effects among the Mega-FTA parties are expected to be huge with its massiveness. Especially, the extensive participation by a number of Eurasian states would likely to promote investment which will eventually contribute to the Eurasia Initiative. As the ultimate goal of the initiative is the economic integration of the Eurasia, Mega-FTAs work together with this goal even with the participation of non-Eurasian states.

\subsection{Mega-FTAs as the Cooperative Game for Investment Promotion in Eurasia}

Here, we can define the strategic partnership among a number of Mega-FTA parties based on the collective rationality as a situation of 'cooperative game'. As the bargaining problem for the joint action through a binding agreement - such as forming the coalitions of 
FTAs - would be a kind of cooperative game (Weirich, 2010 and Gilles, 2010). Plus, since the each state ('singleton coalition') can also selectively form different 'coalition subsets' of FTAs individually with the parties of Mega-FTAs ('grand coalition'), the models of coalitional-form games may apply.

Generally, "a cooperative game in characteristic function form represents the attainable payoffs for the different coalitions directly as collective payoff values. There is no description of the actual, feasible actions available to the individual players in the interactive decision situation. Rather, only the attainable payoff values are described" (Gilles, 2010). This is basically from the model used by Von Neumann and Morgenstern with the following assumptions: "(1) opportunities made to a coalition of players are established without any reference to players outside the coalition, and (2) members of a coalition may conclude costless binding agreements to share the coalition's worth in any way, so that it is not necessary to model explicitly the actions players intend to adopt in order to reach these agreements" (Cochinard, 2002).

Here, let $\mathrm{N}$ be a non-empty finite set of states who consider different cooperation possibilities, in other words, different FTAs. The set $\mathrm{N}$ is called the grand coalition referring to the Mega-FTA and $\Phi$ is called the empty coalition. While $\mathrm{S}$ or $\mathrm{T}$ refers to the each subset of FTAs, $S, T \subset N$. The real number $v(S)$ can be interpreted as the maximal worth - the national interest - that the members of $S$ can obtain when they cooperate. Often we identify the game $(N, v)$ with its characteristic function $v$. Let's denote the collection of coalitions, i.e. the set of all subsets of $N$ by $2^{N}$.

The core of a cooperative game would be the "fundamental stability concept when all coalitions are free to form and automatically reach an efficient agreement (as assumed by the efficiency postulate)" (Moulin, 2002). At this core, there is no individuals or groups who can improve their interests by breaking away or reorganizing a new or independent coalition. If the payoffs structure naturally leads the players to choose the grand coalition of Mega-FTAs, their choices would reach the core of this game. To achieve this core, the cooperative game $(N, v)$ has to be "superadditive" by satisfying the following equation:

$$
\text { All } S, T \in 2^{N} \text { with } S \cap T=\Phi: v(S)+v(T) \leq v(S \cup T)
$$

Would Mega-FTAs be "superadditive" regarding their investment promotion effect? As seen above, there would be the positive national interests for a state by having a FTA since the benefit from the increased inflow of foreign investment will be bigger than the loss. Thus, if there is no injustice in distribution and unfair negotiation, Mega-FTAs at least can be "additive".

Moreover, the external effect of trade liberalization can be greater with the larger 
number of participants in Mega-FTAs. First, since these Mega-FTAs are at the regional level embracing each state's major trading partners, the trade creation effect would exceed the trade diversion effect. Also, as already being the basis of the multilateral trade liberalization, it is obvious that the improved market access for exports of goods and services and foreign direct investment would contribute to this trade creation effect (Schwab and Bhatia, 2014). All participants would come away with improved access to at least one new country market, and in some cases, several new markets. Indeed, the market access motivations heavily influenced RCEP's origins in ASEAN +1 negotiations, and initiatives involving ASEAN +3 and then ASEAN +6 (Schwab and Bhatia, 2014).

Second, more binding power of the agreement can be achieved through the increased peer pressure with many participants, which we have already witnessed through the multilateral trade liberalization system. However, unlike the WTO with a handful of members being blocked to proceed further trade liberalization, Mega-FTAs can provide another opportunity for like-minded countries to achieve higher order agreements consist of more market access than at the WTO level, more generous non-tariff concessions, and more practical rules of origin (Schwab and Bhatia, 2014).

\section{Conclusion: Mega-FTAs can be a Catalyst for the Eurasia Initiative}

While the Eurasia Initiative necessarily involves some economic projects requiring enough investment promotion, Korea can strategically set up the policies linked with the development of Mega-FTAs. Applying the basic game theory, in the non-cooperative game of investment promotion, we could find that the benefit from the foreign investment inflow is the key to persuade other players in Eurasia. Then, as the external factors such as the trade liberalization would positively affect the value of this benefit, the trend of replacing mere BITs by the FTAs is likely to continue. With this regard, the recent development of Mega-FTAs with enlarged scope and the parties may bring a better opportunity for the Eurasia Initiative. To judge on the investment promotive effect of Mega-FTAs, the cooperative game theory can be applied to consider various forms of the coalitions. The important job for Korea to utilize Mega-FTAs for its Eurasia Initiative is to assure this proposition: "the core of the cooperation game would be the grand coalition of a Mega-FTA." If it continues to search for the best policies to maximize the superadditivity of this cooperative game, Korea will finally be able to achieve the co-promotion of Mega-FTAs and the Eurasia Initiative. 


\section{ACKNOWLEDGEMENTS}

The author would like to thank Professor Hyungdoh Hur for supporting the main idea of this paper. 


\section{References}

Ahn, Sanghoon, et al (2005). "The economic impacts of outbound FDI and trade: the case of Korea", OECD Workshop on the Globalisation of Production: Impacts on Employment, Productivity and Economic Growth, Paris. 2005.

Alford, R., (2014). "The Convergence of International Trade and Investment Arbitration", Santa Clara Journal of International Law, 12(1). Symposium on the Law and Politics of Foreign Investment.

Berger, et al (2013). "Do trade and investment agreements lead to more FDI? Accounting for key provisions inside the black box", International Economics and Economic Policy, 10(2), 247-250.

Borensztein, Eduardo, Jose De Gregorio, and Jong-Wha Lee (1998). "How does foreign direct investment affect economic growth?",Journal of international Economics, 45(1), 115-135.

Branzei, Dimitrov, and Tijs (2008). Models in Cooperative Game Theory, Springer.

Byun, Pil-gun (2010). A Handbook of Korea's Investment Treaties, the Ministry of Justice, (in Korean).

Cheong, Inkyo (2013). "The Prospects for Korea's Participation for Mega FTAs in the Asia Pacific Region." CNCPEC Seminar. Beijing.

Cochinard, S. (2002). "The Coalition Concept in Game Theory", in Christian Schmidt (ed.), Game Theory and Economic Analysis, Routledge.

D'Aspremont, Claude and Louis-Andre Gerard-Varet (2002). "Collective Choice Mechanisms and Individual Incentives", in Christian Schmidt (ed.), Game Theory and Economic Analysis, Routledge.

Footer, M. (2013). "On the Laws of Attraction: Examining the Relationship between Foreign Investment and International Trade", in Echandi and Sauve (ed.), Prospects in International Investment Law and Policy, Cambridge University Press. 
Gilles, R. (2010). The Cooperative Game Theory of Networks and Hierarchies, Springer.

Head, K. and John Ries (2001). "Overseas investment and firm exports", Review of International Economics, 9(1), 108-122.

Houde, Kolse-Patil and Miroudot (2007). The Interaction between Investment and Services Chapters in Selected Regional Trade Agreements, 55(6), OECD Publishing.

Hur, N. (2015). "Comparison and Implications of BIT and the Investment Chapter of FTA: Policy Analysis for Korea's Bilateral Investment Negotiations", International Trade Law, Vol. 122, 55-89 (In Korean).

Kang, S. (August 6, 2015). "Park urges N. Korea to join Eurasia Initiative", The Korea Times, available at http://www.koreatimes.co.kr/www/news/nation/ 2015/08/116 184266.html

Kim, June-Dong, and Sang-In Hwang (2000). "The Role of Foreign Direct Investment in Korea's Economic Development: Productivity Effects and Implications for the Currency Crisis", The Role of Foreign Direct Investment in East Asian Economic Development, NBER-EASE Volume 9, University of Chicago Press, 267-294.

Kim, Seungiin (2000). "Effects of outward foreign direct investment on home country performance: evidence from Korea", The Role of Foreign Direct Investment in East Asian Economic Development, NBER-EASE Volume 9. University of Chicago Press, 295-317.

Kim, T. (Februart 16, 2015). "Beyond Geopolitics: South Korea's Eurasia Initiative as a New Nordpolitik", The Asan Forum, available at http://www.theasanforum.org/ beyond-geopolitics-south-koreas-eurasia-initiative-as-a-new-nordpolitik/

Kwon, Y. (August 20, 2014). "South Korea's Eurasia Ambitions", The Diplomat, available at http://thediplomat.com/2014/08/south-koreas-eurasia-ambitions/

Lesher, M., and Miroudot, S. (2006). "Analysis of the Economic Impact of Investment Provisions in Regional Trade Agreements", OECD Trade Policy Papers, No. 36, OECD Publishing. 
Lewis, M. (2015). "TPP and RCEP: Implications of Mega-FTAs for Global Governance", Trans-Pacific Partnership.

Lipsey, Robert E. (2004). "Home-and host-country effects of foreign direct investment", Challenges to globalization: Analyzing the economics, University of Chicago Press, 333-382.

Lo, C. (2008). "A Comparison of BIT and the Investment Chapter of Free Trade Agreement from Policy Perspective", Asian Journal of WTO \& International Health Law and Policy, 3(1), 147-170.

McCain, R. (2010). Game Theory: A Nontechnical Introduction to the Analysis of Strategy, World Scientific Publishing.

Miroudot, S. (2011). "Investment" in Chauffour and Maur (eds.), Preferential Trade Agreement Policies for Development, The World Bank, 319-320,

Mistry of Foreign Affairs (Korea), EurAsia Initiative, available at http://www.mofa.go.kr/ENG/image/common/title/res/0707_eurasia_bro.pdf

Mostafa, G. (2013). "The Concept of 'Eurasia': Kazakhstan's Eurasian Policy and Its Implications", Journal of Eurasian Studies, Volume 4, 160-170.

Moulin, H. (2002). "An Appraisal of Cooperative Game Theory" in Christian Schmidt (ed.), Game Theory and Economic Analysis, Routledge.

Petri and Abdul- Raheem (2014). "Chapter 2 - Can RCEP and the TPP be Path Ways to FTAAP?", State of Trade in the Region Report, Pacific Economic Cooperation Council, 2014), available at http://www.pecc.org/state-of-the-region-report-2014/ 265-state-of-the-region/2014-2015/595-chapter-2-can-rcep-and-the-tpp-be-path-way s-to-ftaap

Qingjiang, K. (2013). "Bilateral Investment Rule-Making: BITs or FTAs with Investment Rules?',The Journal of World Investment and Trade, Volume 14, 638-645.

Sornarajah, M. (1994). The International Law on Foreign Investment, Cambridge University Press. 
Schwab, S. and Karan Bhatia (2014). "The Rationale behind Mega-Regionals - Two View", Mega-Regional Trade Agreement: Game-Changers or Costly Distractions for the World Trading System?, World Economic Forum, 18-21.

UNCTAD (1999). "Trends in International Investment Agreement; An Overview", UNCTAD Series on Issues in International Investment Agreement, United Nations.

UNCTAD (2011). "Scope and Definition", UNCTAD Series on Issues in International Investment Agreement, United Nations.

Weirich, P. (2010). Collective Rationality: Equilibrium in Cooperative Games, (Oxford University Press. 